\title{
Time, Body, Otherness ${ }^{1}$
}

\section{Paula de Lima Trope ${ }^{2}$, English Version: Ana Tereza Prado Lopes ${ }^{3}$}

\begin{abstract}
These elements are recurrent in the artist's work: Time, as duration, in narrative photographs, films and videos that inscribe time in the image; the Body, as a place of experience and where the feminine emerges with political connotation; the Other, in works that deal with encounters, in the constitution of language derived by the contamination between subject and object of the discourse.
\end{abstract}

Keywords: Art, photography, film and video, Time, Body, Otherness.

2 Paula Trope is a visual artist. Bachelor in Cinema, Fluminense Federal University, 1990; Master's degree in Techniques and Poetics in Image and Sound, State University of São Paulo, 1999 and current PhD alumni in History and Art Criticism by the PPGArtes/ UERJ (Postgraduate Studies Arts Program in the State University of Rio de Janeiro). Institutional affiliation: student at Universidade do Estado do Rio de Janeiro, Rua São Francisco Xavier, 524 - Maracanã, Rio de Janeiro - RJ, 20943-000. E-mail: trope. paula@gmail.com. ORCID: https://orcid.org/0000-0001-7504-9691. Lattes ID: http://lattes.cnpq.br/8780570417613223. Rio de Janeiro, Brasil.

3 Artist and curator. BFA from École Supérieure D'Art Visuel, specialization in History of Art and Architecture in Brazil and training in English-Portuguese translation from PUC-Rio. PhD and MFA from EBA / UFRJ (School of Fine Arts/Federal University of Rio de Janeiro). Institutional affiliation: teaches at IART /UERJ (Art Institute of State University of Rio de Janeiro), Rua São Francisco Xavier, 524 - Maracanã, Rio de Janeiro - RJ, 20943-000. E-mail: anaterezapradolopes@gmail.com; ORCID: https:// orcid.org/0000-0001-7582-6040; ID Lattes: 8432791226634568. Rio de Janeiro, Brasil. 


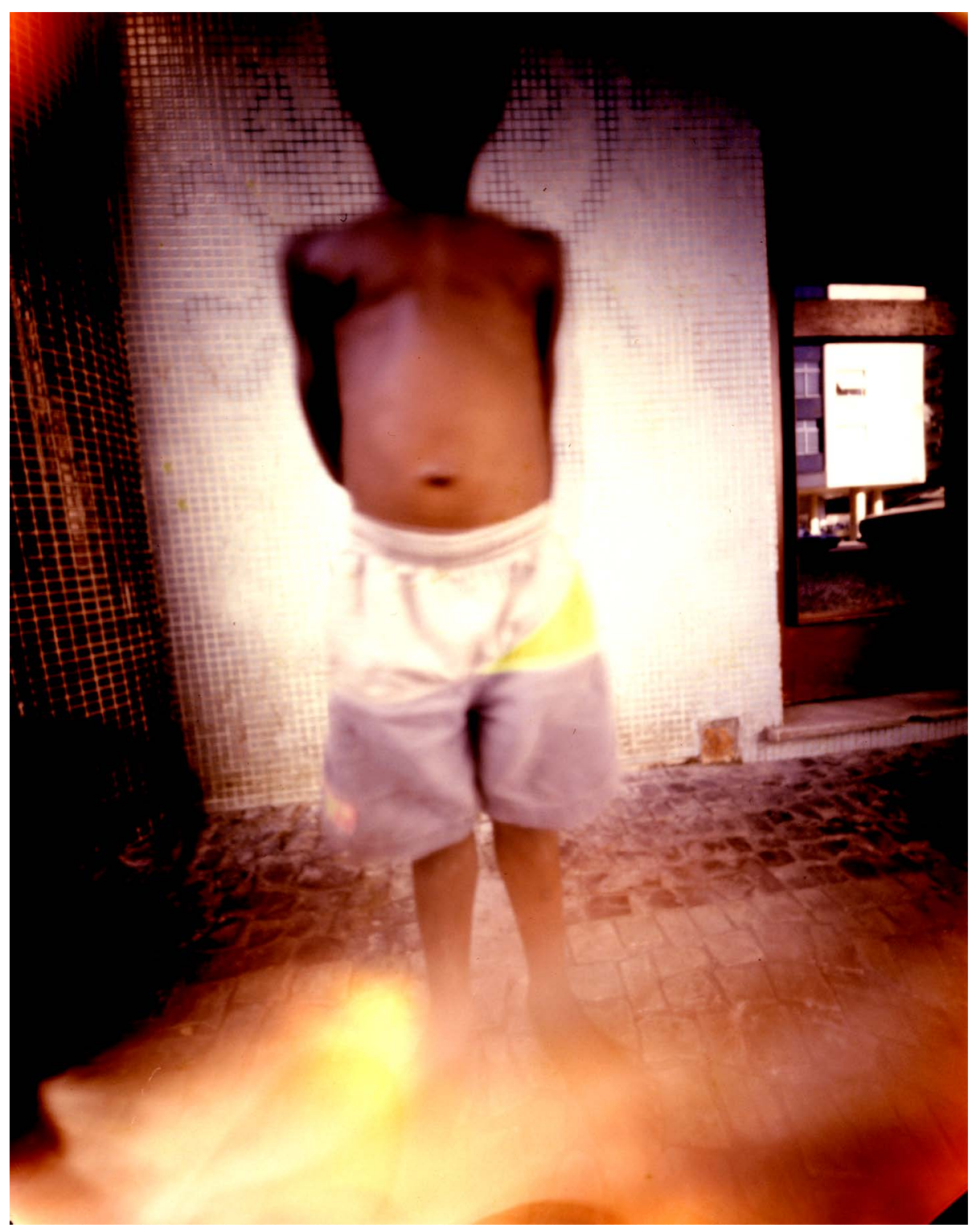

Muller and untitled (the money), 1993 (Diptych of the series Os Meninos (The Boys),

Rio de Janeiro, 1993/1994)

Photograph with pinhole camera Photographic printing on resin colored paper $130 \times 100 \mathrm{~cm}$ and $35 \times 60 \mathrm{~cm}$

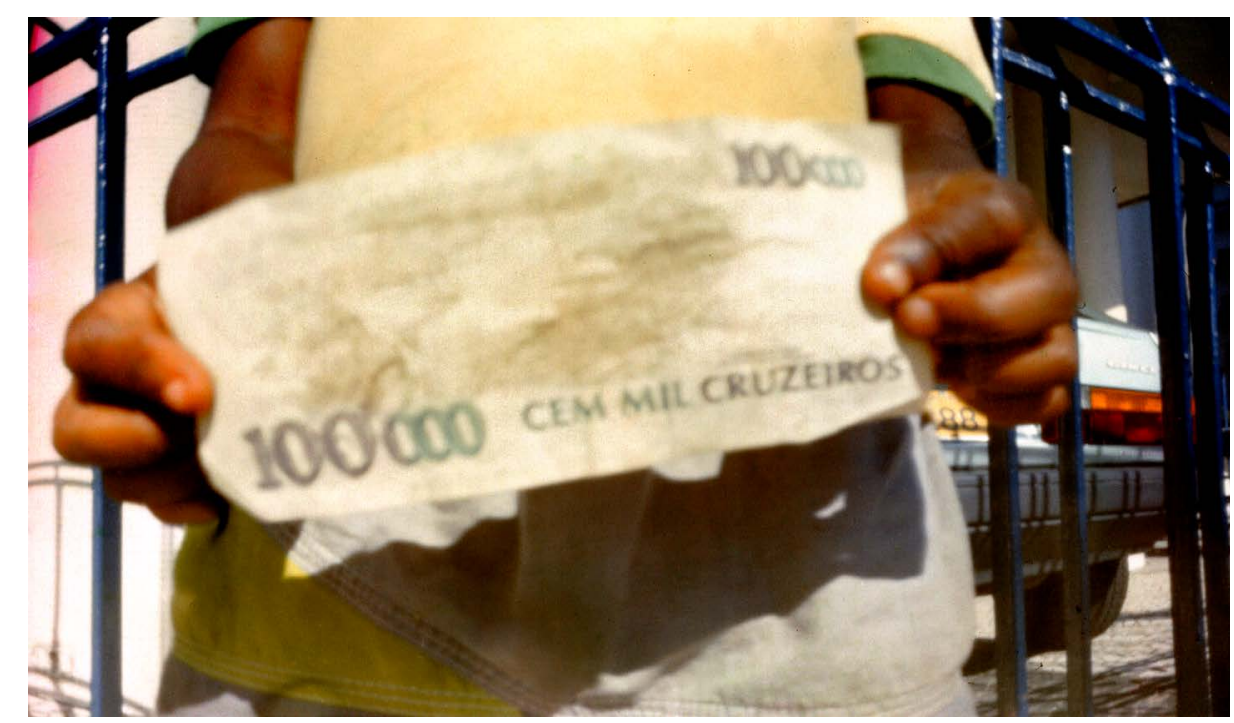


For a better understanding of my work, it's important to highlight my degree in cinema and remember the first Super 8 productions in the 1980's related to the so-called experimental film.

These were decisive essays and studies for later productions that, even being eminently photographic, retain visible influence from cinema - in the scale of the works, in the exploration of sequences, fragmented series and, more specifically, in the matter of Time, that dimension which is abstracted in the passage from cinema (where image gains duration) to photography.

In my work, Time is emphatically represented, it is almost a theme. Taking advantage of different artifices, this is a kind of photography that wants to last and to be analytical, organized in the construction of narratives.

These initial investigations will also define an experimental trace in all subsequent production. They always look for a metalinguistic dimension, taking on a critical stance regarding all mediums used, their criteria of representation, of memory, subjectivity and invention. This also defines the hybrid character of this research, it is a type of photography that is not quite photography or a type of film that is not quite film, oscillating between objectivity and subjectivity, public and private, documentation and fiction.

From another standpoint, recent video productions still reveal Time as a central question. In this research, through filmic resources that produce a suspension of action, but are not translated into movement, time is inscribed in the image, modelling it as its form, achieving a kind of a raccord - a connection - of time. Thus, the image crystallizes, presenting itself as Time in its pure state. ${ }^{1}$

Body is another recurring subject in my work. The fragmented body, rebuilt and brought back to its natural scale in sequencies and photographic series, portraits and self-portraits that invest in the representation of an existential condition of the poetic action's subject. In this sense, the feminine appears as investigation of a way of being, in its fragmented,

1 I here mention the concept of the crystal-image created by Deleuze (1990) referring to the new image of cinema, the time-image, image of hybrid nature, always double or reduplicated, creating a circuit of indistinction between imaginary and the real, actual and virtual becoming thought and operating a direct presentification of time, affect as absolute exteriority, the spirit as the very reality of time. 
Untitled. From the Vulva Series \#2 \# 3\# 7, 2000/2004 Photograph with pinhole camera Photographic printing on resin colored paper each photo $11,2 \times 8,8 \mathrm{~cm}$
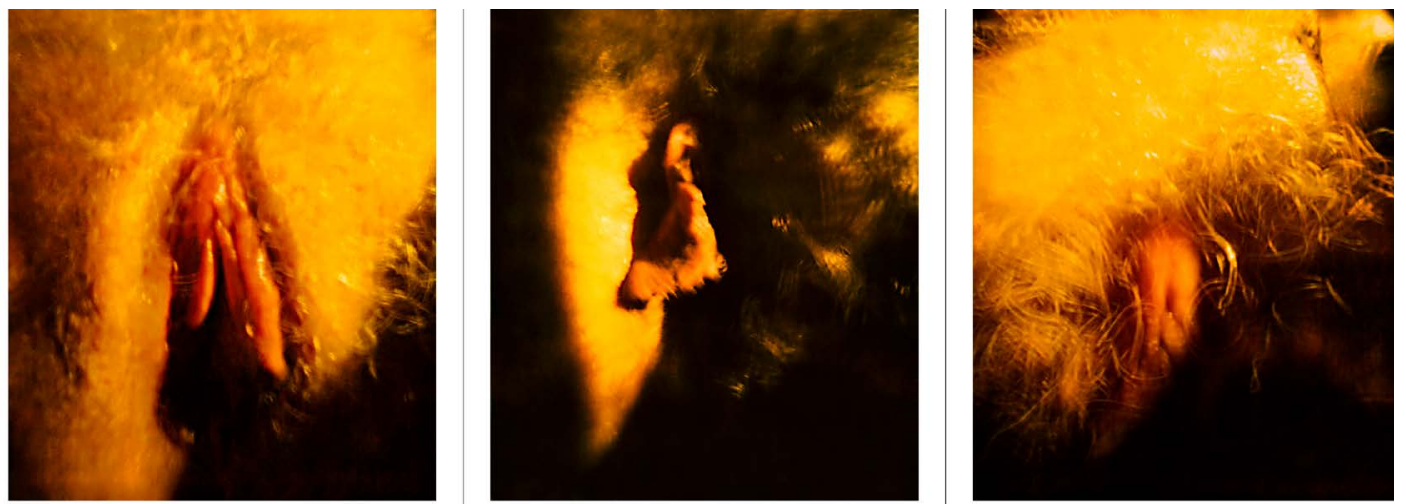

dispersed, multiple and mutant nature. The body as a place, an original situation of experience. The feminine gains an almost political connotation, as a flag, an affirmation of difference, of strangeness.

The body is also a reference in the relation between artwork and space - and in it - with the viewer, with whom it seeks to establish a conversation. Thus, the works present themselves through spatial diagrams, in which scale and installation strategies figure as important elements, always looking for a confrontation with the viewer, in a kind of presentification of the representation.

Last but not least, the Other, in works that deal with the confrontation that surfaces from an encounter - of the constitution of a subject of speech from the contamination between the artistic discourse and that which would be its object. These works have problematized more politically incisive forms of artistic action using photography and, now, video, as mediators in the search for a senses triggering attitude in confrontation with the world.

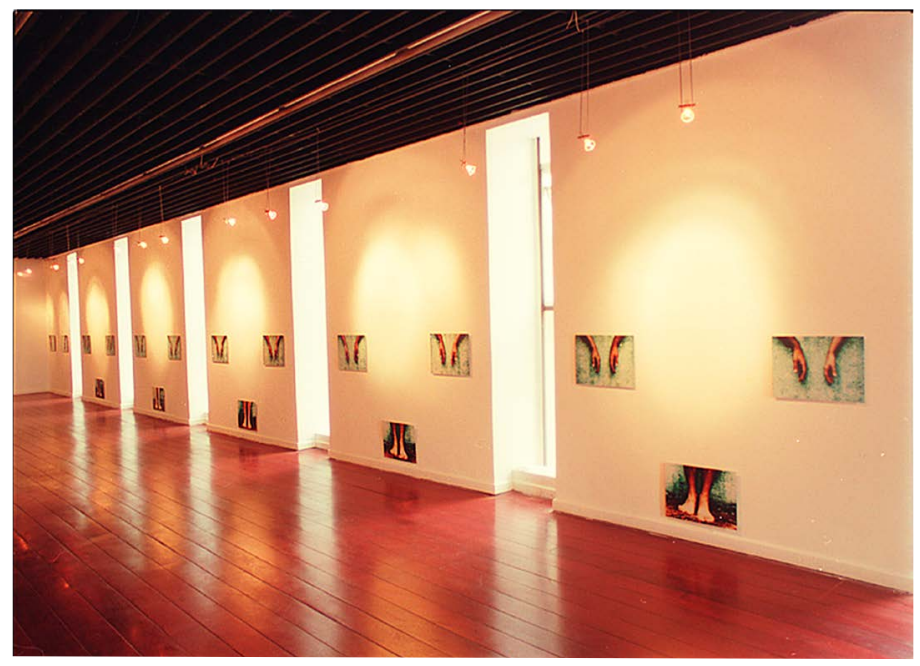


Durâmen (Duramen), 1994

Photographic installation. Photographic series on resin colored paper

Various dimensions. Each photo: 30 x 45 cm; 1993

Photo of the installation in Museu da Imagem e do Som, São Paulo, 1994

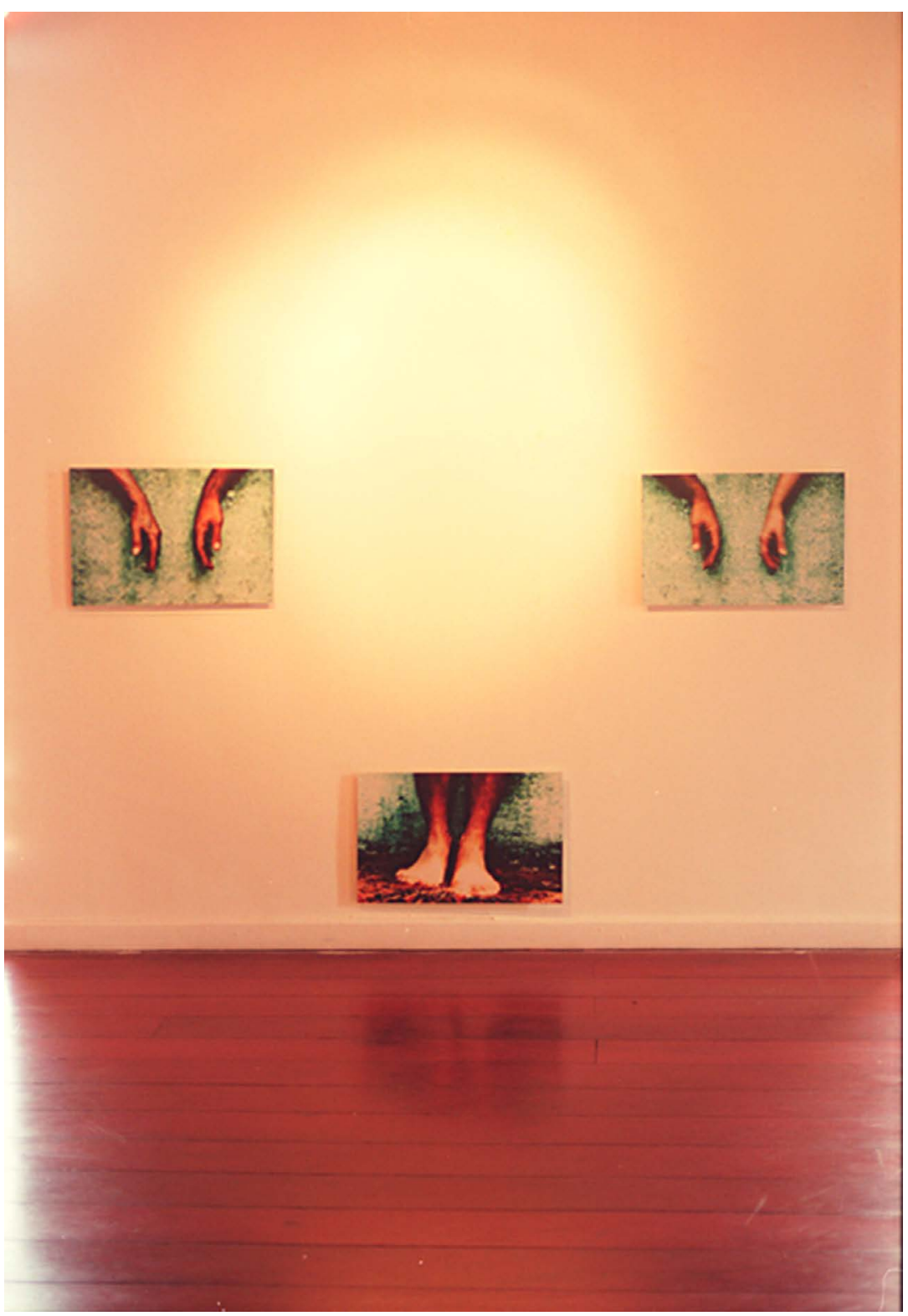

This being said, I present the project Contos de Passagem (Tales of Passage), an experimental video work that brings in its core the issue of Otherness. It is an audiovisual archive composed of testimonials from children and youths that live and work in the streets of Rio de Janeiro, telling their stories. We sought to constitute a geography of the city in the period of the passage of centuries - from December 2000 to December 2001 - from the viewpoint of these boys and girls, circumscribing a kind of symbolic non-place within the urban social fabric. Contos de Passagem (Tales of Passage) is an art object of hybrid character: simultaneously anthropologic, ethnic, documental and poetic. 
The issue of Otherness has been recurrent in my work and appeared, more explicitly, about ten years ago, when I did a project directly related to the one just described, entitled Os Meninos (The Boys), in partnership with street children of Rio de Janeiro.

The work had a dialogical character. A kind of game was proposed: having agreed to be photographed, the child was invited to participate taking pictures of any object of his choice. A "two-way street" was created, where the child at times was the object of the photograph in which he was portrayed and, at others, was the agent of the creative process assuming the role of subject. The performance of the boys put in discussion the position of the artist as someone gifted of a special character, in contrast to the artist as someone capable of producing meaning about the world. In this way, the boys were also creators, collaborators of the work. ${ }^{2}$

Hilton and Felipe, at 13 and 11 .

Arpoador,

February, 2001

Rio de Janeiro, $\mathrm{Dec} / 2000$

Dec/2001. Part 3

Feb/2001

Still of the video

Contos de

Passagem (Tales of

Passage)

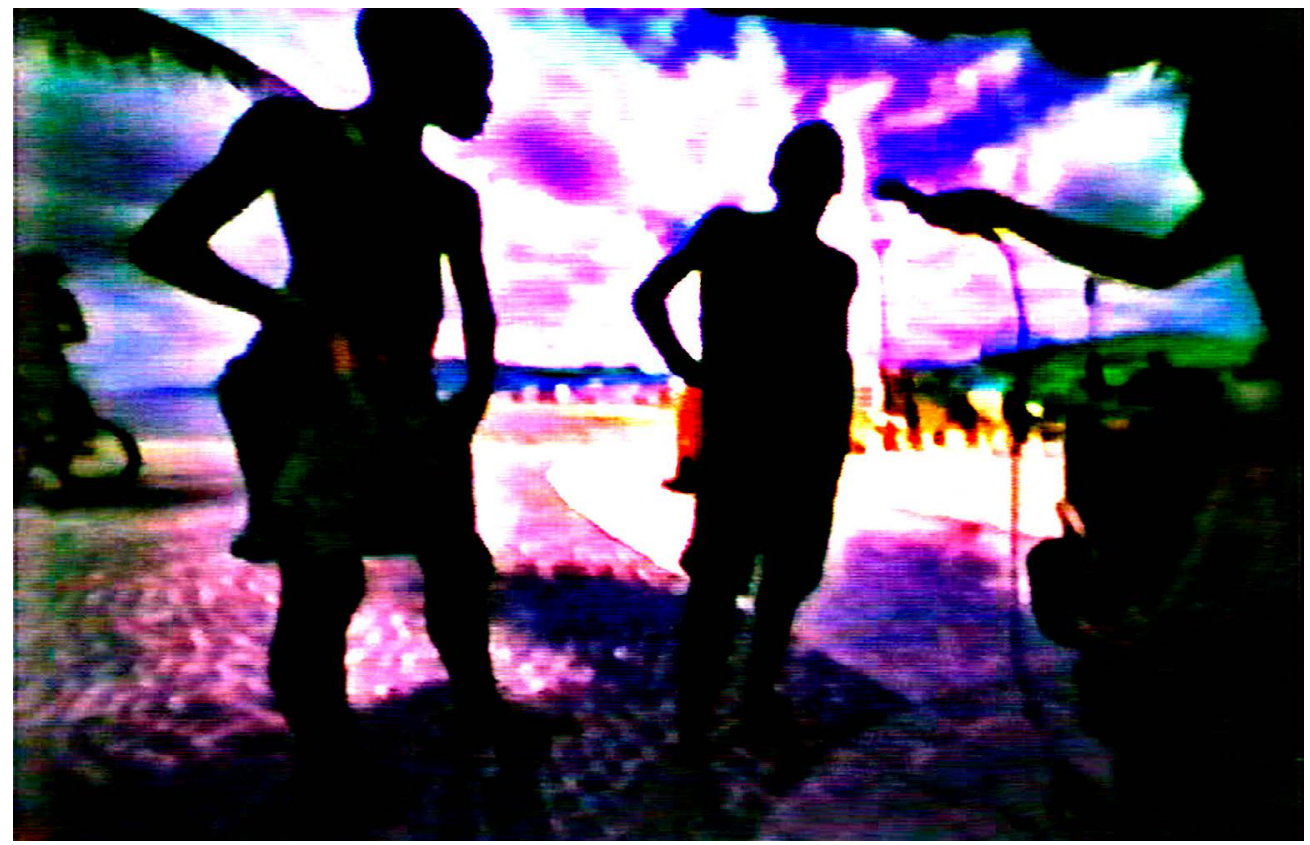

2 Paulo Herkenhoff comments that this work "triggers the potence of symbolization and visibility. The concept of quality, with its arsenal of exclusion, is not at stake. By choosing such a precarious medium (as pinhole cameras) and simultaneously efficient for this political project, Trope and the boys are matched symbolically by technology." (Herkenhoff, 1994:54) 
Bruna, at 10. Copacabana, December 31, 2000 Still of the video Contos de Passagem (Tales of Passage)

Rio de Janeiro $\mathrm{Dec} / 2000$ Dec/2001. Part 1 Dec/2000

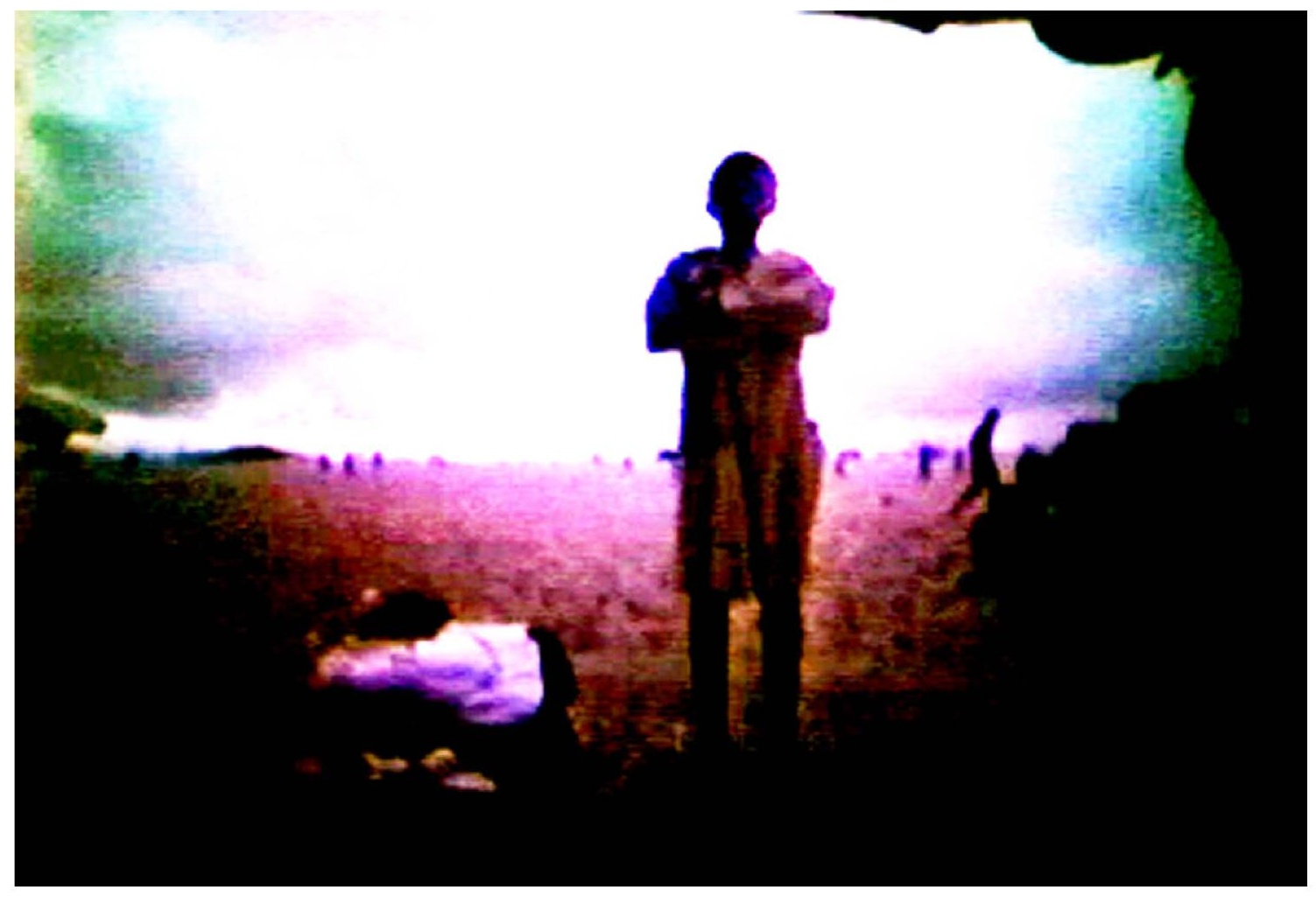

Os Meninos (The Boys) was done with a camera without lenses, both for the aesthetics and the practice involved. Câmeras-furinho (little hole cameras) ${ }^{3}$ are handmade cameras that use the image formation process within a dark environment through a very small orifice. These cameras have no lenses, viewfinder, focus control, lever to pull the film, or shutter button. The produced image is blurry, often undefined, with perspective aberrations, contrary to the norms of the good image. The choice for pinhole cameras is part of a strategy of strangeness ${ }^{4}$ adopted in this and in other works, reworked and incorporated in Contos de Passagem (Tales of Passage).

Another work worth mention as a reference to Contos de Passagem is Traslados (Exchanges), a photographic series done in the cities of Rio de Janeiro, São Paulo and Havana, between 1996 and 1997, for the occasion of

3 Expression used by Alfredo Grieco (1997), emphasizing the essencial fact and minimalist aspect of the camera without lenses.

4 Expression used by Russian Formalists, specially Chklóvski, in the 1920s referring to "a set techniques of construction whose function would be to disturb our daily perceptions and force the sensibility to 'wonder' about the symbolic arrangement that is presented to us.". (Machado, 1984:112, 113) 
the $6^{\text {th }}$ Havana Biennial, in May of the same year. Unlike Os meninos (The Boys), Traslados does not specifically address excluded childhood, and its proposal was to establish a kind of exchange (photographic-poetic-imaginary) between Brazilian and Cuban children managing the exchange of images/messages between them.

The main idea was to produce a work that would speak about Cuba and by reflection, about Brazil. The "game" proposed creating connections and provoking a dialogical situation to investigate connotations that could result from this: information/exchange in an isolation context, language instead of distance, representation of a non-official and non-institutionalized discourse - that of the child.
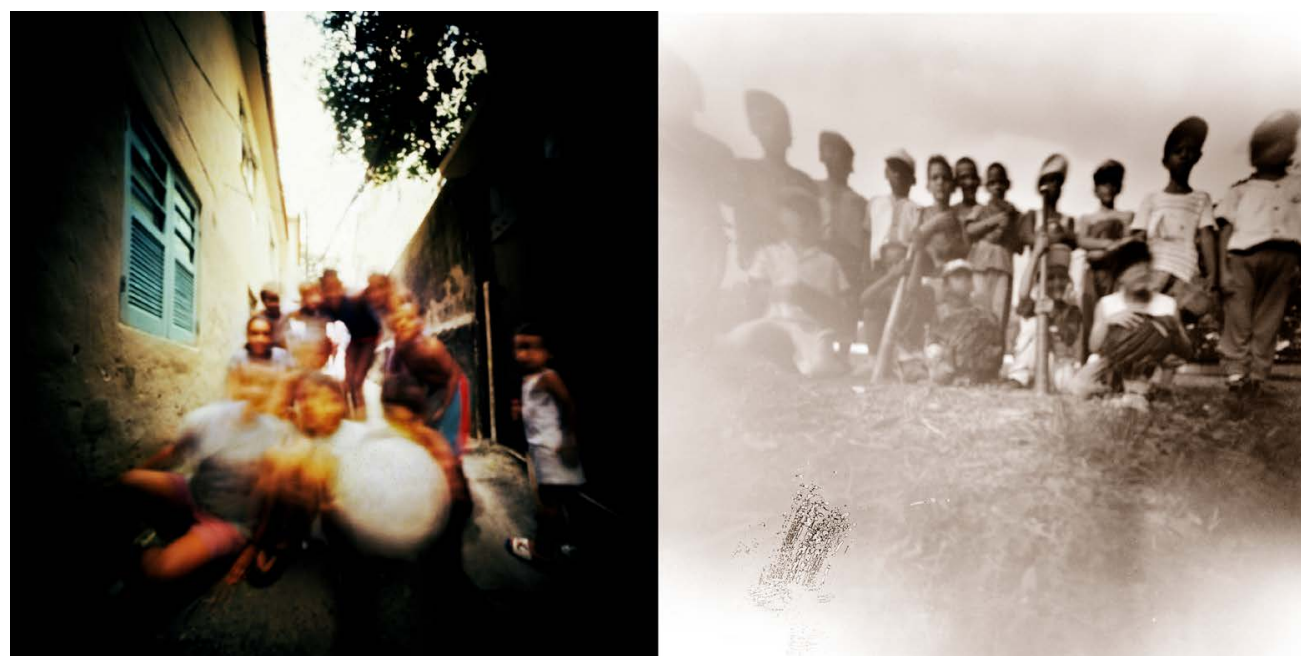

Futebol (Soccer), Rocinha, Rio de Janeiro, 1997 Los Peloteros (The Players). La Lisa, Havana, 1997 Diptych of the series Traslados

(Exchanges),

Brazil - Cuba

$1997 / 1998$

Photograph with pinhole camera Photographic printing on resin colored paper, $2 \times$ $(100 \times 100 \mathrm{~cm})$
Traslados (Exchanges) was shown for the first time in the Havana Biennal, almost simultaneously to its elaboration. In Brazil, the work was expanded in two different formats attaining distinct narrative structures: projected image and artist's book. Traslados (Exchanges) was the object of my Master dissertation in Image and Sound in ECA-USP (Communication School at the University of São Paulo), finished in March, 1999. The narrowing connections between cinema and photography in the course taken by Traslados (Exchanges) led to discussions about the nature of these mediums and the links between them. Traslados (Exchanges) also indicated other possibilities of the artwork's insertion beyond those that had already been brought up by Os Meninos (The Boys).

Contos para 2001 (Tales for 2001) gave me the opportunity to develop some issues already present in Traslados (Exchanges) and Os meninos (The Boys), to problematize and delve into them; how to broaden the docu- 
mental character of the work, its potential to act outside the traditional art circuit, as well as to develop interdisciplinary concepts among art and other fields of knowledge.

Further discussion points - the articulation of a symbolic field for the representation of the Other's imaginary, problematizing the relation subject/object in the work, the gestuality and the dramaticity of the work and also aspects of the image's formal construction, as the adoption of an aesthetics of precariousness and of a primary image technology (camera without lenses, retrograde light weight and low cost filming equipment, editing while shooting, etc...) - unfolded in the transposition of media (photography to video) and were resignified.

Moreover, new elements have come up, as the passage from the image that lasts in the suspension of action in pinhole photography to an image that lasts in the photographic projections and to the image that lasts in the extension of an attitude over time through the material recorded with a fixed film camera. In this sense, orality appears as the most recent data in the repertory of this linguistic fabric.

Rosilene, at 16. Leblon, December $25,2000$.

Stills of the video

Contos de Passagem (Tales of Passage)

Rio de Janeiro, $\mathrm{Dec} / 2000$ -

Dec/2001. Part

$1-\mathrm{Dec} / 2000$

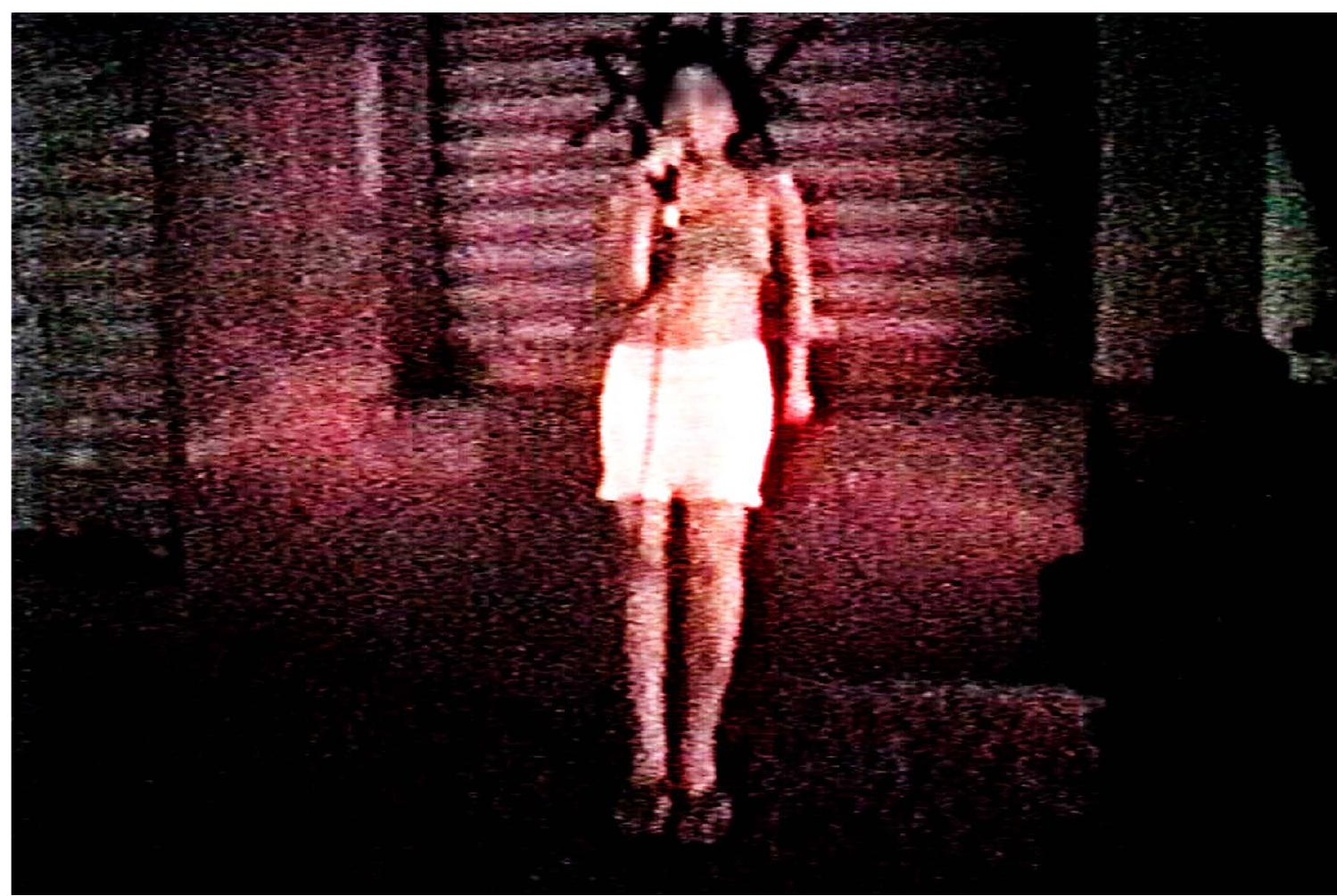


Antonio Marcos, at 13, Barra da

Tijuca, December 2000

Still of the video Contos de Passagem (Tales of Passage)

Rio de Janeiro $\mathrm{Dec} / 2000$ Dec/2001. Part $1-\mathrm{Dec} / 2000$

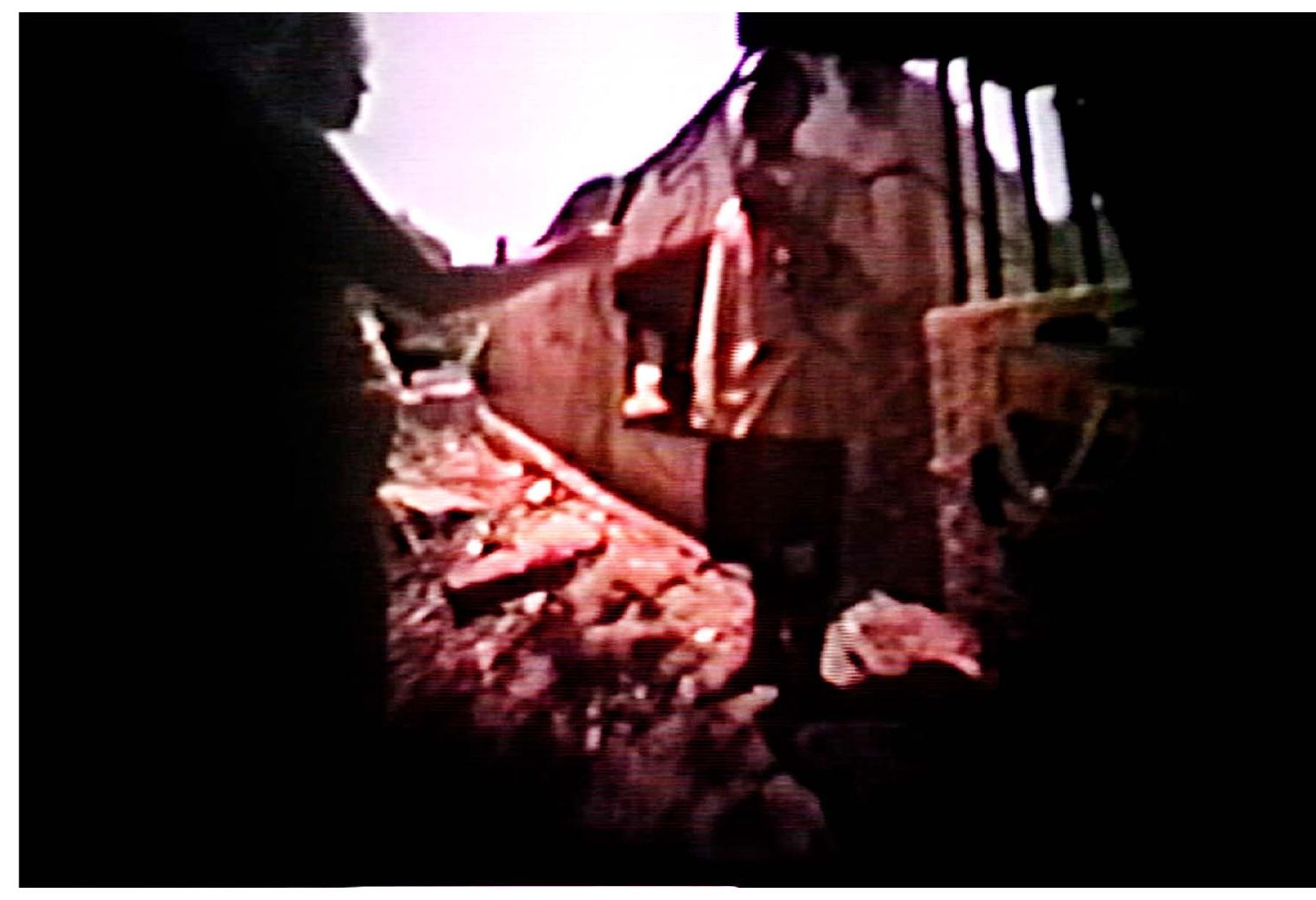

In Contos de Passagem (Tales of Passage), image and sound recordings were made in the formats Super-8, VHS, High- 8 and $16 \mathrm{~mm}$. All the recording devices suffered some interventions in their interior - the original lenses were taken off and a little hole was incorporated in their place. Later, all the material was transferred to digital media to be organized retouched and edited. This mixture of technical means and formats and the experimental character of the use of cameras without lenses ended up configuring a kind of mixed technology, a research of image and movement and its possibilities of experimentation.

The pilot project, a projected videoinstallation was presented in parts one, two and three, relative to the months of December, January and February of that period, in Galeria 1 of Espaço Cultural Sérgio Porto (Rio Arte), from December 16, 2003 to February 2004. The rest of the work remains unpublished.

Agradecimentos a Joana Cseko pela revisão.

Recebido em 14 de dezembro de 2020 e aceito em 14 de dezembro de 2020.

Este é um artigo publicado em acesso aberto sob uma licença Creative Commons (cc) 